International Journal of Heritage, Tourism and Hospitality Vol. (12), No. (1/2), March, 2018

By: Faculty of Tourism and Hotels, Fayoum University

\title{
The Influence of Perceived Organizational Support and Employee Advocacy on Organizational Commitment in Hotels
}

Yasser Abd El-Aty Amr Deraz

Faculty of Tourism and Hotels, Sadat City University

\begin{abstract}
Organizational commitment (OC) achieves numerous positive organizational outcomes as well as positive employee behaviors and attitudes that help the organization to succeed. Hence, it is important to identify employee organizational commitment in hospitality organizations and recognize the factors that influence it, such as perceived organizational support (POS) and employee advocacy. Therefore, the study aimed at investigating the influence of POS and employee advocacy on OC dimensions. For achieving these objectives, data were collected using questionnaires. A convenience sample of 600 hotel employees from 8 five-star hotels in Cairo was chosen for investigation. However, only 367 valid questionnaire forms were received from the respondents, representing a response rate of 61.2 percent. Descriptive analysis, correlation analysis, and multiple regression analysis were used to analyze the data. The findings showed that the two independent factors had significant positive effects on all dimensions of OC. POS as well as employee advocacy had the highest impact on continuance commitment (CC). However, employee advocacy is more important than POS in terms of its impact on normative commitment (NC) and CC. It was recommended that hotel management should increase hotel employees' organizational commitment, particularly the affective commitment (AC), by raising organizational support through many practices, such as organizational rewards, good work conditions, promotion at work, job safety, etc. The results also suggested that hotel management should facilitate the access of employees to required information to improve employee advocacy.
\end{abstract}

Keywords: Perceived organizational support; organizational commitment; affective commitment; normative commitment; continuance commitment; employee advocacy.

\section{Introduction}

This research involves three dependent variables, which are $\mathrm{AC}, \mathrm{NC}$, and $\mathrm{CC}$ as well as two independent variables, which are POS and employee advocacy. OC is an attitude that reflects the relationship between employee and organization. It involves three overall issues: emotional attachment to an organization; feeling a sense of duty and obligation to continue employment because of the social pressure; and feeling committed to an organization based on understanding the costs associated with leaving.

$\mathrm{OC}$ is a key factor to identify organizational behavior and it is one of the best indicators that can be used to predict the employees' turnover (Meyer and Allen, 1997). Several studies found that OC positively influence employee behaviors and attitudes. OC was also found to be negatively related to turnover intention (e.g. Mathieu and Zajac 1990; Meyer et al., 2002).

In addition, OC was found to have positive effects on service quality (Garg and Dhar, 2014). Additionally, a plethora of studies has found that OC positively influences the relationship of the organization with its customers (Boshoff and Allen, 2000; Gounaris, 2005) because it increases customer satisfaction which in turn leads to customer retention and positive word of mouth publicity (Libai et al., 2013).

Furthermore, OC is a strong indicator of organizational effectiveness (Steers, 1977). It is essential for organization success (Uludag et al, 2011). It is an effective response to the whole organization (Morrison, 1996). It appears to be strategically important for employers due to potential financial returns in the long term (Papadakis et al., 1998). Accordingly, it is crucial to 
increase employee organizational commitment in hospitality organizations and identify the factors that influence it, such as POS and employee advocacy.

POS is realized when employees think that their contribution and interests are being respected by organizational practices. Employees who have high POS feel honored, protected, and acknowledged, and in response show raised assistance, identification, gratitude, and persistent work (Chiang and Hsie, 2012). POS usually generates an obligation on employees to make contributions to the organization (Howes et al., 2000), have a concern for the organization's prosperity, and help the organization achieve its goals (Armeli et al., 2002; Chew and Wong, 2008; Dhar, 2012).

Employees recognize the support obtained from their organization and consequently have a feeling of obligation to it (Eisenberger et al., 1990; Rhoades and Eisenberger, 2002). This obligation makes employees feel and show commitment towards their organizations (Wayne et al., 1997).

As regards to employee advocacy, it means that the organization represents and supports the interests of employees. The employee advocacy perception is developed as a consequence of assessing management practice (O'Fallon, 2014). When management defends employees' interests, the trust of employees and their positive behaviors and feelings towards the organization increase (Akgunduz and Sanli, 2017).

In the literature there are few studies looking into the concept of employee advocacy (e.g. Yeh, 2014; Akgunduz and Sanli, 2017). No study in the areas of hospitality management has measured to date the influence of employee advocacy on employees' organizational commitment.

As a result, the purpose of this study is to explore the extent to which employees in five-star hotels in Cairo perceive organizational support and employee advocacy as well as to assess their commitment to the organization. In addition, the study investigates the impact of POS and employee advocacy on OC dimensions.

The research was conducted on the category of five-star hotels where the concepts of organization support and employee advocacy are applied, therefore they can be measured. Also, these types of hotels are managed by international hotel chains or franchised. Thus, when the research is conducted on these hotels, the results obtained will be obvious and can then be applied on the other categories of hotels (i.e. three or four-star hotels).

\section{Literature review}

\section{Perceived organization support}

The idea of organizational support is derived from the social exchange theory (SET) (Blau, 1964) and Norm of Reciprocity Theory (NRT) (Gouldner, 1960). According to these two theories, employees who are offered a favor by their organizations will not harm these organizations and will show positive feelings and behaviors towards them.

The POS concept was first introduced by Eisenberger et al. (1986) to explain the reciprocations between employees and their organization. POS is regarded as a social exchange connection that stems from interactions between an employee and his or her organization. It is described as a psychological contract that the employee makes with the enterprise (Eisenberger et al., 2004). It also refers to individuals' "global beliefs concerning the extent to which the organization values their contribution and cares about their well-being" (Eisenberger et al., 1986, p. 501).

The antecedents and consequences of POS and its mediating and moderating roles between many variables were identified. Examples of the antecedents that help to develop POS include organization justice, managerial support, organizational rewards, work conditions, promotion at work, job safety, etc. (Riggle et al., 2009). POS consequences include organizational 
commitment, job satisfaction, job performance, job involvement, low levels of voluntary quitting, and positive work behaviors (Rhoades and Eisenberg, 2002).

POS is supposed to be as a strong predictor of OC (Eisenberger et al., 1986). It has been found to be associated with employee commitment to the organization (Eisenberger et al., 1990; Muse and Stamper, 2007; Panaccio and Vandenberghe, 2009). POS was found to be the real cause of OC (Rhoades et al., 2001).

\section{Organizational commitment}

OC means the degree to which an employee identifies with an organization (Malik et al., 2010; Mehrabi et al., 2013). It is also conceptualized as an acceptance of the organizational objectives (Robbins and Coulter, 2012; Alniaçik et al., 2013), a willingness to work hard to accomplish those objectives (Porter et al., 1974; Su et al., 2013), and the desire to remain with the organization (Porter et al., 1974; Meyer and Allen, 1991; Greenberg and Baron, 2000; Robbins and Judge, 2013).

From business managers' viewpoint, OC is very necessary to bring, maintain, and motivate key individuals (Michaels et al., 2001). In addition, OC was found to positively influence employee behaviors, including work effort, organizational citizen behaviors, job performance (e.g., Mathieu and Zajac 1990; Meyer et al., 2002), absenteeism (Joiner and Bakalis, 2006), cooperative behaviors, efficiency, and productivity of employees (Eisenberger et al., 2010; Lub et al., 2012).

OC comprises three components, i.e. AC (feelings-based), NC (obligation-based), and CC (costbased) (Meyer and Allen, 1991; Becker, 2009). This classification is broadly accepted and came as the superior one (Allen and Meyer, 1996; Powell and Meyer, 2004; Gellatly et al., 2006). On the other hand, Bergman (2006) and Solinger et al. (2008) argued that AC and NC are highly correlated practically although they differ from each other theoretically. Therefore, there is a slight difference between these two concepts. In contrast, $\mathrm{CC}$ has almost no relationship with either AC or NC (Solinger et al., 2008; Wallace et al., 2013).

\section{Affective commitment}

$\mathrm{AC}$, the most studied dimension of $\mathrm{OC}$, is defined as a strong belief in and acceptance of the goals and values of an organization (Porter et al., 1974). In addition, it is "an emotional attachment to, identification with, and involvement in to an organization" (Allen and Meyer, 1990, p. 1). The employee who is driven by AC stays in the job because he likes his organization, enjoys the working relationship, and feels a sense of loyalty and belongingness (Mathieu and Zajac 1990; Somers 1995; Robbins and Judge, 2013).

Reichers (1985) suggested that AC indicates a higher level of commitment, while NC and CC show moderate and low levels of commitment, respectively. AC has stronger positive effects on organizational outcomes, such as turnover intentions and performance, compared to the other two types of commitments (Tett and Meyer, 1993; Meyer et al., 2002; Joarder et al., 2011; Luo et al., 2013a; 2013b). AC also influences both the continuance and normative commitment (He et al., 2011). AC is the most influential dimension to understand employee behavior among the three dimensions of OC (Malik et al., 2010; Dhar, 2015; Jaiswal and Dhar, 2016).

Eisenberger et al. (1986) proposed that when employees believe that the organization cares about their well-being, they feel obliged to return the caring by developing AC. Several researchers (e.g. Armeli et al., 2002; Wayne et al., 2002) provide support for this assumption, indicating that POS and AC are strongly related. Depending upon the existing literature, POS is believed to be positively associated with the AC. Thus, following hypothesis is made. 
Hypothesis 1. POS positively influences AC.

\section{Normative commitment}

$\mathrm{NC}$ is described as "a feeling of obligation to continue employment" (Meyer and Allen, 1997, p. 11). In this commitment category, employees "feel that they ought to remain with the organization" (Meyer and Allen, 1991, p. 67). They stay in the job because of the social pressure, the moral and ethical values, or the responsibility toward the organization, in spite of the degree of job satisfaction (Tufail and Naveed, 2012). NC happens when employees feel loyal and indebted to organization that gave them a lot of advantages (Powell and Meyer, 2004; Weng et al., 2010). Individuals with a strong NC do not desire to dissatisfy their supervisors and colleagues if they depart the organization (Greenberg and Baron 2000).

There is a positive relationship that has also been found between POS and NC (e.g. Meyer et al., 2002; Maertz et al., 2007). This relationship between POS and NC is based on internalized normative pressures (Weiner, 1982) in addition to social exchange and reciprocity to positive work experiences (Maertz et al., 2007). Based on the existing literature, POS is expected to be positively linked with the NC. Therefore, following proposition is made.

Hypothesis 2. POS positively influences NC.

\section{Continuance commitment}

$\mathrm{CC}$ is the extent to which employees feel committed to their organizations based on the costs associated with leaving. Employees may remain in an organization because of the investments they have made or the costs/benefits related to leaving (Jaros 2007; Tufail and Naveed, 2012). Antecedents of CC include magnitude and/or the number of personal investments, monetary rewards, alternative work options, and organization specific skills (Jaros et al., 1993; Nazem and Mozaiini, 2014).

Therefore, CC may be believed as a self-centered feeling (Powell and Meyer, 2004). It is different from AC because there is no affective bond with the organization in CC category. Employees who have $\mathrm{CC}$ continue to stay in the organization because they need this. They are considered to be less committed to organization than affective employees (Meyer and Allen, 1991).

$\mathrm{CC}$, as opposed to AC and NC displays modest consistent negative relationships with POS (e.g. Meyer et al., 2002; Rhoades et al., 2001; Powell and Meyer, 2004). In addition, Tetrick et al. (1991) argued that low POS may increase the "negative form of commitment" reflected in CC. Based on the prior research, POS is supposed to be positively associated with the CC. Thus, the following proposition is made.

Hypothesis 3. POS positively influences CC.

\section{Employee advocacy}

Employee advocacy is defined as the straightforwardness of the organization's employment policy, and its readiness to accomplish the best interests of the staff, although solution to a problem is recommended by the competitors (Urban, 2004). Another definition is a method of supporting and enabling employees to convey their opinions and concerns, to gain access to information and services, to defend and announce their rights and responsibilities, and to discover choices and options (UK Essays, 2015). Employee advocacy includes issues, such as taking the employees' complaints into account, maintaining them from discriminatory employment practices, behaving to employees appropriately (e.g. promotion and transfer), and avoiding them from harassment (Kim, 2009). 
Employee advocacy widely spreads in organizations that respect and give value for their staff. On the contrary, it is not adopted in those organizations where the employees are dealt worthlessly (Rynes, 2004). Management support of workers directly influences employee advocacy. This leads staff to maintain and create extra effort for fulfilling their work for a long term (Yeh, 2014).

There are several benefits of applying employee advocacy in organizations. It positively affects organizational productivity (Mathieu and Zajac, 1990), job satisfaction (Chen, 2006; Chen, 2008; Petrescu and Simmons, 2008) and OC (Park and Rainey, 2007). Moreover, employee advocacy was found to positively influence job embeddedness (e.g. Yeh, 2014; Akgunduz and Sanli, 2017). In addition, it was found to decrease the turnover intention (Yeh, 2014). Likewise, in this research it is expected that the employee advocacy affect the OC positively. In addition, depending on the SET, RNT, and the existing literature, employee advocacy is believed to be positively associated with $\mathrm{AC}, \mathrm{NC}$, and $\mathrm{CC}$. Thus, the following hypotheses have been developed.

Hypothesis 4. Employee advocacy positively influences AC.

Hypothesis 5. Employee advocacy positively influences NC.

Hypothesis 6. Employee advocacy positively influences CC.

\section{Research methodology}

Based on previous research, this study was designed to assess five variables in hotels: two independent variables (i.e. POS and employee advocacy) and three dependent variables (i.e. AC, $\mathrm{NC}$, and $\mathrm{CC}$ ). Moreover, the research examines the effect of the independent variables on the three dependent variables.

\section{Measurement and instrument}

A questionnaire of three main parts was designed for the purpose of this research. The first part (POS) was composed of 6 items (Eisenberg et al., 2001). The second part (OC) comprised three sections: AC (9 items) (Meyer et al., 1993); NC (5 items) (Meyer and Allen, 1991); and CC (2 items) (Meyer and Allen, 1991). The final part (employee advocacy) included 6 items (Eisenberger et al., 1986). A five-point Likert scale was used in all sections of the survey (1= strongly disagree and $5=$ strongly agree).

\section{Population and sample}

The target population for the study was employees of all five-star hotels (33 hotels) in Cairo (Egyptian Hotel Guide, 2016). After conducting a pilot study, it was found that only 8 five-star hotels accepted to distribute the questionnaire to their employees and that the whole number of employees in each hotel is almost equal. Thus, a convenience sample of 600 hotel employees from the eight hotels was chosen for investigation. The questionnaire forms were equally distributed to these eight hotels ( 75 per hotel). Only 367 complete questionnaires were received, representing a response rate of 61.2 percent. The questionnaire forms were distributed and collected by hand to the investigated sample of employees during period from 7-2017 to 8-2017.

\section{Validity and reliability of the study instrument}

With regards to the validity of the survey scales, face validity was established by seeking the perceptions of several hotel employees toward the appropriateness of the questionnaire and whether it rang true for them or not. Moreover, the questionnaire was initially pre-tested for its validity by handing it out to human resources specialists and a professor of human resources. 
Based on the comments and suggestions obtained from the pre-test, necessary improvements were made and some mistakes were corrected. In addition, the scale validity includes the collection of empirical evidence concerning its use (Pallant, 2007). In this research, the 5 scales constituting the survey were used and tested by previous researchers. For example, POS scale was used by many previous scholars (Eisenberg et al., 2001).

In terms of reliability, Cronbach's alpha coefficient was calculated to determine the internal consistency of the scales used in the research. Cronbach's coefficient alpha indicates greater reliability if its value is higher than .7 (Pallant, 2007). In this study, all the values of Cronbach's coefficient alpha were above .7 which indicated that the instrument was reliable.

\section{Data analysis}

Data analysis depended on using SPSS package (Statistical Package for the Social Sciences)

version (16) to analyze the data. Mean scores and standard deviations are calculated for all factors in the study. Pearson correlation coefficient was used at a significance level of 5\% to find the relationship between POS, employees' advocacy, and the three OC dimensions (i.e. AC; NC; CC). The hierarchal multiple regression at a significance level of 5\% was used to determine the strength of the relationship between variables of the study.

\section{Results and discussion \\ Sample characteristics}

The questionnaire included four items concerning the respondents' demographic characteristics, i.e. gender, age, educational level, and hotel department. Regarding gender, $70.5 \%$ of hotel employees were male and $29.5 \%$ of them were female. Concerning age, about $65 \%$ of the respondents were aged from 20 to less than 40 years, while approximately $35 \%$ of them were aged from 40 to 55 years. In regards to educational level, the majority of hotel employees (89\%) graduated from university, $9 \%$ of them graduated from high school, and only $2 \%$ of them were post graduates. In terms of hotel department, $40 \%$ of hotel employees were from the housekeeping department, 55\% of them were from the food and beverage department, and finally $10 \%$ of them were from the front office department.

\section{A descriptive analysis of POS, employee advocacy, and OC dimensions}

This analysis was conducted to assess employees' perceptions regarding the variables of POS, employee advocacy, and OC in hotels. SPSS for Windows version 16 was used to descriptively analyze all items related to the previous variables by their means and standard deviations (Table 3).

Table (1) shows that the mean scores of the overall POS and employee advocacy were 3.8 and 4, respectively. Also, the results clarified that OC dimensions, which are AC, NC, and CC, had means of 4, 4.3, and 1.6, respectively. This indicates that all investigated factors (i.e. POS; employee advocacy; OC dimensions) were accepted by hotel employees with the exception of $\mathrm{CC}$ dimensions which were perceived disagreeably.

Table 1: A descriptive analysis of POS, employee advocacy, and OC items

\begin{tabular}{|l|c|c|c|}
\hline \multicolumn{1}{|c|}{ Perceived organizational support items } & $\begin{array}{c}\text { Cronbach's } \\
\text { alpha }\end{array}$ & Mean & $\begin{array}{c}\text { Std. } \\
\text { deviation }\end{array}$ \\
\hline $\begin{array}{l}\text { POS } \\
\text { special favis hotel is willing to help me when I need a }\end{array}$ & .875 & 4.3 & .4432 \\
\hline POS $_{2}$ : This hotel values my contributions to its well- & .914 & 4.2 & .3462 \\
\hline
\end{tabular}


International Journal of Heritage, Tourism and Hospitality Vol. (12), No. (1/2), March, 2018 By: Faculty of Tourism and Hotels, Fayoum University

\begin{tabular}{|c|c|c|c|}
\hline being. & & & \\
\hline $\begin{array}{l}\mathrm{POS}_{3} \text { : This hotel takes pride in my accomplishments at } \\
\text { work. }\end{array}$ & .901 & 4.1 & .8295 \\
\hline $\begin{array}{l}\mathrm{POS}_{4}: \text { This hotel strongly considers my goals and } \\
\text { values. }\end{array}$ & .911 & 4 & .5732 \\
\hline $\mathrm{POS}_{5:}$ This hotel cares about my opinions. & .785 & 4 & .6453 \\
\hline $\mathrm{POS}_{6}$ : This hotel shows very little concern for me. & .901 & 2 & .1472 \\
\hline Employee advocacy items & .901 & 4 & .8462 \\
\hline $\begin{array}{l}\text { EA }_{1} \text { : The hotel provides information that enables } \\
\text { employees to choose between different options. }\end{array}$ & .911 & 4.3 & .3462 \\
\hline $\begin{array}{l}\text { EA }_{2} \text { : The hotel provides its employees with tools to } \\
\text { help them solve their problems. }\end{array}$ & .911 & 4.2 & .7862 \\
\hline $\begin{array}{l}\text { EA }_{3} \text { : The hotel attempts to represent the employees' } \\
\text { best interests. }\end{array}$ & .901 & 4 & .4562 \\
\hline $\begin{array}{l}\mathrm{EA}_{4}: \text { The hotel attempts to improve employee } \\
\text { satisfaction. }\end{array}$ & .912 & 4 & .9672 \\
\hline $\begin{array}{l}\text { EA }_{5} \text { : The hotel enables employees to share information } \\
\text { about their experiences when using various products } \\
\text { and services. }\end{array}$ & .912 & 4 & .3414 \\
\hline $\begin{array}{l}\text { EA }_{6} \text { : The hotel provides complete and open information } \\
\text { for employees. }\end{array}$ & .911 & 3.5 & .7562 \\
\hline \multicolumn{4}{|l|}{ Cont. table (1) } \\
\hline \multicolumn{4}{|l|}{ Organizational commitment } \\
\hline Affective organizational commitment items & & & \\
\hline $\mathrm{AC}_{1}:$ This organization deserves my loyalty & .911 & 4.7 & .4085 \\
\hline $\begin{array}{l}\mathrm{AC}_{2}: \mathrm{I} \text { am proud to tell people that I am part of this } \\
\text { institution }\end{array}$ & .901 & 4.6 & .5890 \\
\hline $\begin{array}{l}\mathrm{AC}_{3} \text { : I really feel as if this organization's problems are } \\
\text { my own. }\end{array}$ & .911 & 4.5 & .6032 \\
\hline $\begin{array}{l}\mathrm{AC}_{4}: \text { This organization has a great deal of personal } \\
\text { meaning for me }\end{array}$ & .911 & 4.5 & .6640 \\
\hline $\mathrm{AC}_{5}:$ I feel emotionally attached to this organization & .912 & 4.3 & .4830 \\
\hline $\begin{array}{l}\mathrm{AC}_{6}: \mathrm{I} \text { would be very happy to spend the rest of my } \\
\text { career in this organization }\end{array}$ & .911 & 4.2 & .5430 \\
\hline $\mathrm{AC}_{7}$ : I feel like part of my family at this organization & .902 & 4 & .5324 \\
\hline $\mathrm{AC}_{8}:$ I owe a great deal to this organization & .911 & 4 & .3462 \\
\hline $\begin{array}{l}\mathrm{AC}_{9} \text { : I do not feel a strong sense of belonging to this } \\
\text { organization. }\end{array}$ & .914 & 2 & .4021 \\
\hline Normative organizational commitment items & & 4.3 & \\
\hline $\begin{array}{l}\mathrm{NC}_{1} \text { : It would not be morally right for me to leave this } \\
\text { company now }\end{array}$ & .911 & 4.4 & .9022 \\
\hline $\begin{array}{l}\mathrm{NC}_{2}: \text { I feel a personal responsibility to continue } \\
\text { working for this organization: }\end{array}$ & .913 & 4.3 & .5442 \\
\hline $\begin{array}{l}\mathrm{NC}_{3} \text { : If I got another offer for a better job elsewhere, I } \\
\text { would not feel it was right for me to leave my } \\
\text { organization: }\end{array}$ & .911 & 4.3 & .7562 \\
\hline $\begin{array}{l}\mathrm{NC}_{4} \text { : Even if it were to my advantage, I do not feel it } \\
\text { would be right to leave my organization now: }\end{array}$ & .911 & 4.2 & .3302 \\
\hline $\mathrm{NC}_{5}$ : I would feel guilty if I left this organization now & .901 & 4.1 & .9472 \\
\hline
\end{tabular}




\begin{tabular}{|l|c|c|c|}
\hline \multicolumn{1}{|c|}{ Continuance organizational commitment items } & & 1.6 & \\
\hline $\begin{array}{l}\mathrm{CC}_{1} \text { : There's no too much to be gained by sticking with } \\
\text { this organization indefinitely }\end{array}$ & .901 & 2 & .3762 \\
\hline $\begin{array}{l}\mathrm{CC}_{2} \text { : Often, I find it difficult to agree with this } \\
\text { organization's policies on important matters relating to } \\
\text { its employees. }\end{array}$ & .901 & 1.2 & .3542 \\
\hline
\end{tabular}

As shown in table 1, it could be noticed that POS elements $\left(\mathrm{POS}_{1}, \mathrm{POS}_{2}, \mathrm{POS}_{3}, \mathrm{POS}_{4}, \mathrm{POS}_{5}\right.$, and $\mathrm{POS}_{6}$ ) achieved mean scores of 4.3, 4.2, 4.1, 4, 4, and 2, respectively. With regards to $\mathrm{POS}_{4}$ statement (i.e. this hotel shows very little concern for me), it expresses satisfactory commitment although mean score is below four.

Furthermore, the results in table 1 clearly stated that employee advocacy elements $\left(\mathrm{EA}_{1}, \mathrm{EA}_{2}\right.$, $\mathrm{EA}_{3}, \mathrm{EA}_{4}, \mathrm{EA}_{5}$, and $\mathrm{EA}_{6}$ ) had means of 4.3, 4.2, 4, 4, 4, and 3.5, respectively. It is clear from this table that $\mathrm{EA}_{6}$ (i.e. providing complete and open information for employees in the hotel) got the lowest mean score (3.5). This finding revealed that the employees were not satisfied about the quality and quantity of information provided to them by management. Hence, there is a necessity for hotel management to facilitate the access of employees to complete information.

In addition, from the previous tabulated data it can be seen that $\mathrm{AC}$ elements $\left(\mathrm{AC}_{1}, \mathrm{AC}_{2}, \mathrm{AC}_{3}\right.$, $\mathrm{AC}_{4}, \mathrm{AC}_{5}, \mathrm{AC}_{6}, \mathrm{AC}_{7}, \mathrm{AC}_{8}$, and $\left.\mathrm{AC}_{9}\right)$ recorded means of $(4.7,4.6,4.5,4.5,4.3,4.2,4,4$, and 2) respectively. In addition, most of $\mathrm{AC}$ elements had average scores above four, indicating that employees' $\mathrm{AC}$ was satisfactory. Moreover, $\mathrm{AC}_{9}($ mean $=2)$ also expresses acceptable commitment although it is below 4 because the statement (i.e. I do not feel a strong sense of belonging to this organization) is negative.

Furthermore, the previous tabulated data indicated that $\mathrm{NC}$ items $\left(\mathrm{NC}_{1}, \mathrm{NC}_{2}, \mathrm{NC}_{3}, \mathrm{NC}_{4}\right.$, and $\mathrm{NC}_{5}$ ) reported means of 4.4, 4.3, 4.3, 4.2, and 4.1, respectively. All NC scores had average scores above four, indicating that employees showed acceptable NC. In terms of employees' $\mathrm{CC}$, the two items (i.e. $\mathrm{CC}_{1}$ and $\mathrm{CC}_{2}$ ) reported means of 2 and 1.2 respectively, expressing satisfactory commitment although they were below 4 because $\mathrm{CC}$ is a negative form of commitment. These findings are consistent with Tetrick's et al. (1991) who argued that CC reflects a negative form of commitment reflected in $\mathrm{CC}$.

\section{Relationship between POS, employee advocacy and OC dimensions}

To indicate the relationship between POS, employee advocacy and OC dimensions, a correlation was measured. The results obviously exposed that, there were significant relationships among all these variables. These results are presented in tables 2 and 3.

Table 2: Correlation between POS and OC dimensions

\begin{tabular}{|c|c|c|c|}
\hline & & POS & AC \\
\hline \multirow{3}{*}{ POS } & Pearson correlation & 1 & .762 \\
& Sig. (2-tailed) & & .000 \\
& $N$ & 367 & 367 \\
\hline \multirow{3}{*}{ AC } & Pearson correlation & .762 & 1 \\
& Sig. (2-tailed) & .000 & 367 \\
\hline & $N$ & 367 & NC \\
\hline \multirow{3}{*}{ POS } & & POS & .876 \\
& Pearson correlation & 1 & .000 \\
& Sig. (2-tailed) & & 367 \\
\hline
\end{tabular}


International Journal of Heritage, Tourism and Hospitality Vol. (12), No. (1/2), March, 2018 By: Faculty of Tourism and Hotels, Fayoum University

\begin{tabular}{|c|c|c|c|}
\hline \multirow{3}{*}{ NC } & Pearson correlation & .876 & 1 \\
& Sig. (2-tailed) & .000 & 367 \\
\hline & $N$ & 367 & CC \\
\hline \multirow{3}{*}{ POS } & Pearson correlation & 1 & .830 \\
& Sig. (2-tailed) & & .000 \\
& $N$ & 367 & 367 \\
\hline \multirow{3}{*}{ CC } & Pearson correlation & .830 & 1 \\
& Sig. (2-tailed) & .000 & 367 \\
\hline
\end{tabular}

**Correlation is significant at the 0.05 level (2-tailed).

The findings clearly revealed that there are positive relationships between POS and the three dimensions of OC: NC ( $r=0.876$, Sig. <0.000); CC ( $r=0.830$, Sig. <0.000); and AC ( $r=0.762$, Sig. $<0.000$ ), respectively (see table 2 ). This means that if POS increases, OC dimensions will increase.

Additionally, it is clear from table (3) that there are positive relationships between employee advocacy and all OC dimensions. Furthermore, it was clearly noticed that CC achieved the highest score of correlation $(r=0.715$, Sig. $<0.000)$, whereas AC got the lowest score $(r=0.480$, Sig. <0.000).

Table 3: Correlation between employee advocacy and OC dimensions

\begin{tabular}{|c|c|c|c|}
\hline & & Employee advocacy & $\mathrm{AC}$ \\
\hline \multirow{3}{*}{$\begin{array}{l}\text { Employee } \\
\text { advocacy }\end{array}$} & Pearson correlation & 1 & .480 \\
\hline & Sig. (2-tailed) & & .000 \\
\hline & $N$ & 367 & 367 \\
\hline \multirow{4}{*}{$\mathrm{AC}$} & Pearson correlation & .480 & 1 \\
\hline & Sig. (2-tailed) & .000 & \\
\hline & $N$ & 367 & 367 \\
\hline & & Employee advocacy & $\mathrm{NC}$ \\
\hline \multirow{3}{*}{$\begin{array}{l}\text { Employee } \\
\text { advocacy }\end{array}$} & Pearson correlation & 1 & .675 \\
\hline & Sig. (2-tailed) & & .000 \\
\hline & $N$ & 367 & 367 \\
\hline \multirow{4}{*}{$\mathrm{NC}$} & Pearson correlation & .675 & 1 \\
\hline & Sig. (2-tailed) & .000 & \\
\hline & $N$ & 367 & 367 \\
\hline & & Employee advocacy & $\mathrm{CC}$ \\
\hline \multirow{3}{*}{$\begin{array}{l}\text { Employee } \\
\text { advocacy }\end{array}$} & Pearson correlation & 1 & .715 \\
\hline & Sig. (2-tailed) & & .000 \\
\hline & $N$ & 367 & 367 \\
\hline \multirow{3}{*}{$\mathrm{CC}$} & Pearson correlation & .715 & 1 \\
\hline & Sig. (2-tailed) & .000 & \\
\hline & $N$ & 367 & 367 \\
\hline
\end{tabular}

$* *$ Correlation is significant at the 0.05 level (2-tailed).

\section{Regression results of $\mathrm{POS}$ and employee advocacy with $\mathrm{OC}$ dimensions}

Multiple regression analysis was conducted to determine whether the two independent variables (i.e. POS and employee advocacy) affect the dependent variables, which are OC dimensions or not (see tables 4 and 5).

The first regression analysis was used to assess the degree of influence of POS on the three OC dimensions based on the previously mentioned correlation, as shown in table (4). Concerning 
$\mathrm{NC}$, it was found to be positively influenced by POS (R-square $=.490, \mathrm{P}$-value=.000). The present finding concurs with other studies (e.g. Meyer et al., 2002; Maertz et al., 2007).

Table 4: POS influencing OC dimensions

\begin{tabular}{|c|c|c|c|c|c|}
\hline \multirow[b]{2}{*}{ Variables } & \multicolumn{3}{|c|}{ Un-standardized coefficients } & \multirow{2}{*}{$\begin{array}{l}\text { Sig. } \\
.000\end{array}$} & \multirow[t]{2}{*}{ Model statistics } \\
\hline & B & Std. Error & & & \\
\hline Constant & .089 & .020 & R-square & .000 & \multirow{4}{*}{$F: 14.8903$} \\
\hline $\mathrm{AC}$ & .045 & .059 & 401 & .000 & \\
\hline $\mathrm{NC}$ & .198 & .032 & .490 & .000 & \\
\hline $\mathrm{CC}$ & .325 & .099 & .592 & .000 & \\
\hline
\end{tabular}

Regression equation can be formed as $\mathrm{POS}=.089+.045 \mathrm{AC}+.198 \mathrm{NC}+.325 \mathrm{CC}$.

In terms of $\mathrm{AC}$, it was also found to be positively affected by POS (R-square =. 401, Pvalue=.000). In this regard, several researchers (e.g. Armeli et al., 2002; Wayne et al., 2002) found a positive relationship between POS and AC. This result also provided support for the assumption of Eisenberger et al. (1986) who stated that employees feel obliged to develop AC if they believe that the organization cares about their well-being.

As regards to the dimension of $\mathrm{CC}$, it was also found to be positively affected by POS (R-square $=.592$, P-value $=.000)$. This finding is consistent with the results of previous research (e.g., Meyer et al., 2002; Rhoades et al., 2001; Powell and Meyer, 2004).

The hypotheses 1, 2, and 3 predicted that POS would have a positive effect on NC, CC, as well as AC. These three hypotheses are supported. The findings showed that employees who perceive that their organization supports them have higher levels of $\mathrm{NC}, \mathrm{AC}$, and $\mathrm{CC}$.

The second regression analysis (see table 5) was used to assess the degree of influence of employee advocacy on the three OC dimensions. They all were found to be significantly affected by employee advocacy [i.e. (CC) R-square $=.69$, P-value $=.000$; (NC) R-square $=.60$, Pvalue $=.000 ;(\mathrm{AC}) \mathrm{R}$-square $=.30, \mathrm{P}$-value=.000], respectively. These findings are in agreement with those of Park and Rainey's (2007) which showed that employee advocacy positively affects OC.

Table 5: Employee advocacy influencing dimensions

\begin{tabular}{|c|c|c|c|c|c|}
\hline \multirow[b]{2}{*}{ Variables } & \multicolumn{3}{|c|}{ Un-standardized Coefficients } & \multirow{2}{*}{$\begin{array}{l}\text { Sig. } \\
.000\end{array}$} & Model Statistics \\
\hline & $\mathrm{B}$ & Std. Error & R-square & & \multirow{5}{*}{$F: 18.2890$} \\
\hline Constant & .754 & .060 & & .000 & \\
\hline $\mathrm{AC}$ & .097 & .077 & .30 & .000 & \\
\hline $\mathrm{NC}$ & .134 & .054 & .60 & .000 & \\
\hline $\mathrm{CC}$ & .087 & .043 & .69 & .000 & \\
\hline
\end{tabular}

Regression equation can be formed as employee advocacy $=.754+.097 \mathrm{AC}+.134 \mathrm{NC}+.087$

$\mathrm{CC}$

The previous regression results are also supported by the two social theories (i.e. SET and NRT). The former one supposes that employees are obliged to return a favor after benefiting from another person or group (Blau, 1964). The latter posits that "people should help those who have helped them" as well as "people should not injure those who have helped them" in the process of human interchange (Gouldner, 1960, p.171).

It was expected that employee advocacy would have a positive effect on $\mathrm{NC}, \mathrm{AC}$, and $\mathrm{CC}$ dimensions. These hypotheses $(4,5$, and 6) are also supported. This finding supports the argument that employees, who perceive that employers value their interests, have positive attitudes towards their organization. 
Second, the influence of POS and employee advocacy on AC is not strong as compared to the other two dimensions, although AC indicates a higher level of commitment, while the normative and continuance dimensions of commitment show moderate and low levels of commitment (Reichers, 1985). Third, the figure illustrates that employee advocacy is more important than POS in terms of its impact on OC dimensions (NC; CC). This may be due to that providing POS is more expected by staff than the employee advocacy which may exceed the expectations of employees. This coincides with the study of Yeh (2014) who stated that employee advocacy leads workers to create extra effort for accomplishing their work for a long term.

Figure 1: Research framework

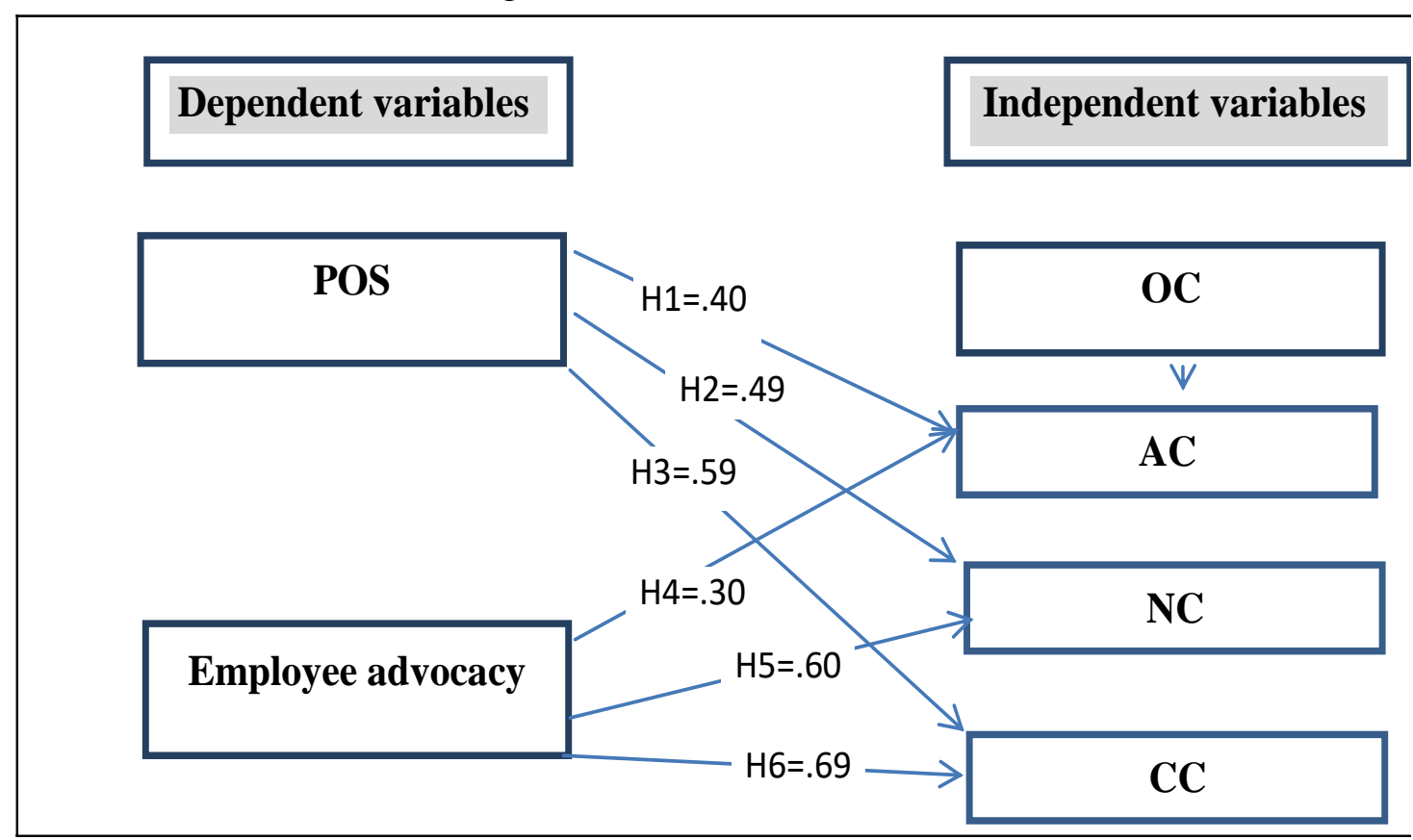

\section{Conclusion and implications}

The study aims at identifying the effect of POS and employee advocacy on OC dimensions (i.e. $\mathrm{AC}, \mathrm{NC}$, and $\mathrm{CC}$ ). The results have certified that there are positive effects of the POS and employee advocacy on the three dimensions of OC. This study could be useful for hotel management in the following: (1) regarding POS, hotel management can increase hotel employees' organizational commitment by raising organizational support through many practices as providing organization justice, organizational rewards, good work conditions, promotion at work, job safety, etc.; (2) concerning employee advocacy, hotel management should facilitate the access of employees to required information. This can be occurred through presenting sufficient information about the products and services of the hotel (e.g. facilities available, amenities, restaurants and lounges, transport services, attractions, etc.) via the intranet, which may consist of a single network or several interlinking networks within all hotel departments. These types of networks give employees easy access to information unavailable through conventional channels, such as delivering printed papers (Gilbert et al., 1999), resulting in less paper consumption and costs. In addition, hotel management can also provide an extranet for their employees, which is partially accessible to authorized outsiders by username and password. This allows more accessibility to networked resources and information (Nassar, 2002). 


\section{Limitations and future research}

The study has several limitations which also pave the way for further research. First, the sample includes only hotels from one city in Egypt and this may weaken the generalization of the research results. Another limitation of this research is that it investigated the organizational support and employee advocacy only from employees' viewpoints. Further research could try to assess hotel managers' behaviors in terms of support and advocacy towards their employees with the intention that employees' perceptions and behaviors of hotel managers are matched. An additional limitation of this study is that it examined the effect of organizational support and employee advocacy only on employees' organizational commitment. Future research could also identify the impact of POS and employee advocacy on staff turnover intention.

\section{References}

Akgunduz, Y., \& Sanli, S. C. (2017). The effect of employee advocacy and perceived organizational support on job embeddedness and turnover intention in hotels. Journal of Hospitality and Tourism Management, 31, 118-125.

Allen, N. J. \& Meyer, J. P. (1996). Affective, Continuance, and Normative Commitment to the Organization: An Examination of Construct Validity. Journal of Vocational Behavior, 49, 3, 250-278.

Allen, N.J. \& Meyer, Y.P. (1990). The measurement and antecedents of affective, continuance and normative commitment to the organization. Journal of Occupational Psychology, 63, 1-18.

Alniaçik, E., Alniaçik, U., ERAT, S. \& Akcin, N. (2013) Does person-organization fit moderate the effects of affective commitment and job satisfaction on turnover intentions. Social and Behavioral Sciences, 99, $274-281$.

Armeli, S., Eisenberger, R., \& Rhoades, L. (2002).Affective commitment to the organization: The contribution of perceived organizational support. Journal of Applied Psychology, 86, 5, 825-836.

Becker, T.-E. (2009). Interpersonal commitments. In Commitment in organizations: Accumulated wisdom and new directions, ed. Cited in. Klein, H. J. L. Becker, T. E. \& Meyer, J. P. 13778. New York: Routledge.

Bergman, M.E. (2006). The relationship between affective and normative commitment: review and research agenda. Journal of Organizational Behavior, 27 (5), 645-663.

Blau, P. (1964). Exchanges and Power in Social Life. New York, NY, John Wiley.

Boshoff, C., \& Allen, J. (2000). The influence of selected antecedents on frontline staff's perceptions of service recovery performance. International Journal of Service Industry Management, $11(1), 63-90$.

Chen, C.C. (2008). Test of a mediating model linking perceived organizational sup- port and job performance. Journal of Management (Taiwan) 25 (3), 309-331.

Chen, C.F. (2006). Job satisfaction, organizational commitment, and flight attendants' turnover intention: a note. Journal of Air Transport Management, 12, 274-276.

Chew, Y. T., \& Wong, S. K. (2008). Effects of career mentoring experience and perceived organizational support on employee commitment and intentions to leave: a study among hotel workers in Malaysia. International Journal of Management, 25(4), 692-700.

Chiang, C.F., \& Hsieh, T.S. (2012). The impacts of perceived organizational support and psychological empowerment on job performance: the mediating effects of organizational citizenship behavior. International Journal of Hospitality Management, 31 (1), 180-190.

Dhar, R.L. (2015). Service quality and the training of employees: the mediating role of organizational commitment. Tourism Management, 46, 419-430.

Dhar, R. L. (2012). Caregiving for elderly parents: a study from the Indian Perspective. Home Health Care Management \& Practice, 24(5), 242-254. 
Eisenberger, R. (2002). Perceived Supervisor Support: Contribution to Perceived Organizational Support and Employee Retention. Journal of Applied Psychlogy, 87(3), 565-573.

Eisenberger, R., Aselage, J., Sucharski, I. L., \& Jones, J. R. (2004). Percived Organizational Support, The Employment Relationship: Examining Psychological and Contextual Perspectives, Oxford University Press, 206-225.

Eisenberg R., Hutington, R., Hutchinson S., \& Sowa, D. (1986). Perceived Organizational Support. Journal of Applied Psychology, 71(3), 500-507.

Eisenberger, R., Rexwinkel, B., Lynch, P.D., \& Rhoades, L. (2001). Reciprocation of perceived organizational support. Journal of Applied Psychology, 86, 42-51.

Eisenberger, R., Stinglhamber, F., Becker, T.E., Karagonlar, G., Neves, P., \& Gonzalez-Morales, M.G. (2010). Leader-member exchange and affective organizational commitment: the contribution of supervisor's organizational embodiment. Journal of Applied Psychology, 95 (6), 1085-1103.

Eisenberger, R., Fasolo, P., \& Davis-LaMastro, V., (1990). Perceived organizational support and employee diligence, commitment, and innovation. J. Appl. Psychol. 75 (1), 51.

Garg, S., \& Dhar, R.L. (2014), "Effects of stress, LMX and perceived organizational support on service quality: mediating effects of organizational commitment". Journal of Hospitality and Tourism Management, 21, 64-75.

Gellatly, I. R., Meyer, J. P., \& Luchak, A. A. (2006). Combined effects of the three commitment components on focal and discretionary behavior: A test of Meyer and Herscovitch's propositions. Journal of Vocational Behavior, 69, 331-345.

Gilbert, D., Powell-Perry, J., \& Widijoso, S. (1999) Approaches by hotels to the use of the internet as a relationship marketing tool, Journal of Marketing Practice - Applied Marketing Science, 5, $1,21-38$.

Gouldner, A.W. (1960). The norm of reciprocity: A preliminary statement. American Sociological Review, 25(2), 161-178.

Gounaris, S.P. (2005).Trust and commitment influences on customer retention: insights from business-tobusiness services. Journal of Business Research, 58 (2), 126-140.

Greenberg J., \& Baron R.A. (2000), Behavior in Organizations ( $7^{\text {th }}$ edition). Upper Saddle River, New Jersey: Prentice-Hall Publishing.

He, Y., Li, W. \& Lai, K.K. (2011). Service climate, employee commitment and customer satisfaction: evidence from the hospitality industry in China. International Journal of Contemporary Hospitality Management, 23 (5), 592-607.

Howes, J. C., Cropazano, R., Grandey, A. A., \& Mohler, C. J. (2000). Who is Supporting Whom? Quality Team Effectives and Perceived Organizational Support. Journal of Quality Management, 5, 207-223.

Jaiswal, D., \& Dhar, R.L. (2016). Impact of perceived organizational support, psychological empowerment and leader member exchange on commitment and its subsequent impact on service quality. International Journal of Productivity and Performance Management, 65 (1), $58-79$.

Jaros, S. (2007). Meyer and Allen model of organizational commitment: Measurement issues. The ICFAI Journal of Organizational Behavior , 6 (4): 7-26.

Jaros, S.J., Jermier, J.M., Koehler, J.W. \& Sincich, T. (1993). "Effects of continuance, affective, and moral commitment on the withdrawal process: an evaluation of eight structural equation models". Academy of Management Journal, 36 (5), 951-95.

Joarder, M., Sharif, M. \& Ahmed, K. (2011). Mediating role of affective commitment in HRM practices and turnover intention relationship: A study in a developing context. Business and Economics Research Journal, 2(4), 135-158. 
Joiner, T., \& Bakalis, S. (2006). The Antecedents of Organizational Commitment: The Case of Australian Casual Academics. International Journal of Educational Management, 20 (6), 439-452.

Kim, D.O. (2009). Employees' perspective on non-union representation: A comparison with unions. Economic and Industrial Democracy, 30(1), 120-151.

Libai, B., Muller, E., \& Peres, R. (2013). Decomposing the value of word-of-mouth seeding programs: acceleration versus expansion. Journal of Marketing Research, 50(2), 161-176.

Lub, X., Bijvank, M.N., Bal, P.M., Blomme, R. \& Schalk, R. (2012).Different or alike? Exploring the psychological contract and commitment of different generations of hospitality workers. International Journal of Contemporary Hospitality Management, 24(4) , 553-573.

Luo, Z., Marnburg, E., Ogaard, T., \& Larsen, S. (2013a).Antecedents for employee helping behavior in the hospitality industry. Journal of China Tourism Research, 9(4), 395-412.

Luo, Z., Qu, H., \& Marnburg, E. (2013b). Justice perceptions and drives of hotel employee social loafing behavior. International Journal of Hospitality Management, 33, 456-464.

Maertz, C. P., Jr., Griffeth, R. W., Campbell, N. S., \& Allen, D. G. (2007). The effects of perceived organizational support and perceived supervisor support on employee turnover. Journal of Organizational Behavior, 28, 1059-1075.

Malik, O. F., Waheed, A., \& Malik, K. (2010). The mediating effects of job satisfaction on role stressors and affective commitment. International Journal of Business and Management, 5(11), 223235.

Mathieu J.E., \& Zajac, D.M. (1990). A Review and Meta-Analysis of the Antecedents, Correlates, and Consequences of Organizational Commitment. Psychological bulletin, 108 (2), 171-194.

Mehrabi, J., Alemzadeh, M., \& Jadidi, M. (2013). Explaining the Relationship between Organizational Structure and Dimensions of Learning Organizations (Case study: Education Organization in Boroojerd County and the Related Departments). International Journal of Academic Research in Business and Social Sciences, 3 (4), 116-128.

Meyer, J.P., \& Allen, N.J. (1991). A three-component conceptualization of organizational commitment. Journal of Human Resource Management Rev,1,61-89.

Meyer, J., \& Allen, A. (1997). Commitment in the Workplace: Theory, Research, and Application. Thousand Oaks, CA: Sage Publications.

Meyer, J. P., Allen, N. J. and Smith, C. A. (1993). Commitment to organizations and occupations: extension and test of a three component conceptualization. Journal of Applied Psychology, 78 (4), 538-551.

Meyer J.P., Stanley, D., Herscovitch, L., \& Topolnytsky, L. (2002). Affective, Continuance, and Normative Commitment to the Organization: A Meta-analysis of Antecedents, Correlates, and Consequences. Journal of Vocational Behavior, 61, 20-52.

Michaels, E., Handfield-Jones, H., \& Axelrod, B. (2001). The war for talent. Boston: Harvard Business School Press.

Morrison, E.W. (1996). Organizational citizenship behavior as a critical link between HRM practices and service quality. Human Resource Management, 35 (4), 493-512.

Muse, L. A., \& Stamper, C. L. (2007). Perceived organizational support: Evidence for a mediated association with work performance. Journal of Managerial Issues, 19(4), 517-535.

Nassar, M., (2002). An evaluation of the World Wide Web (web) as a strategic marketing tool for the Egyptian hotel sector. PhD. thesis, The University of Wales.

Nazem, F., \& Mozaiini, M. (2014). Investigating the relationship between the organizational commitment and job involvement in employees at Islamic Azad University of Roudehen, Damavand, Pardis, and Boomehen to provide an appropriate model. Bulletin of Environment, Pharmacology and Life Sciences, 3 (1), 107-113. 
O'Fallon, J. (2014). Powering internal communication for employee advocacy: Competitive advantage begins with employees who understand and want to share the electric co-op story. Yayımlanmamıs, yüksek lisans tezi. ABD: University of Minnesota.

Pallant, J. (2007). SPSS survival manual: A step by step guide to data analysis using SPSS for windows. $3^{\text {th }}$ ed. New York, McGraw Hill.

Panaccio, A., \& Vandenberghe, C. (2009). Perceived organizational support, organizational commitment and psychological well-being: a longitudinal study. Journal of Vocational Behavior, 75(2), 224-236.

Papadakis, V. M., Lioukas, S., \& Chambers, D. (1998). Strategic decision-making

processes: the role of management and context. Strategic Management Journal, 19 (2), 115-147.

Park, S.M., Rainey, H.G. (2007). Antecedents, mediators, and consequences of affective, normative, and continuance commitment: empirical tests of commitment effects in federal agencies. Review of Public Personal Administration, 27, 197-226.

Petrescu, A.I., Simmons, R., (2008). Human resource management practices and worker's job satisfaction. International Journal of Man Power. 29 (7), 651-667.

Porter L.W., Mowday, R.T., Steers R.M., \& Boulian, P.(1974). Organizational commitment, job satisfaction and turnover among psychiatric technicians. Journal of Applied Psychology, 59 (5), 603-609.

Powell, D. M., \& Meyer, J. P. (2004). Side-bet theory and the three-component model of organizational commitment. Journal of Vocational Behavior, 65(1), 157-177.

Reichers, A.E. (1985). A Review and Reconceptualization of Organizational Commitment. Academy of Management Review, 10 (3): 465-76.

Rhoades, L., \& Eisenberger, R. (2002). Perceived organizational support: A review of the literature. The Journal of Applied Psychology, 87, 698-714.

Rhoades, L., Eisenberger, R., \& Armeli, S. (2001). Affective commitment to the organization: The contribution of perceived organizational support. Journal of Applied Psychology, 86, 825836.

Riggle, R. J., Edmondson, D. R., \& Hansen, J. D. (2009). A meta-analysis of the relationship between perceived organizational support and job outcomes: 20 years of research. Journal of Business Research, 62 (10), 1027-1030.

Robbins, S. P., \& Coulter, M. (2012), Management", $7^{\text {th }}$ ed. New Jersey, Prentice-Hall.

Robbins, S. P., \& Judge, T. A. (2013). Organizational behavior $\left(15^{\text {th }}\right.$ ed.). New Jersey, Prentice-Hall

Rynes, S. L. (2004). Where do we go from here? Imagining new roles for human resources. Journal of Management Inquiry, 13 (3), 203-213.

Solinger, O.N., van Olffen, W., \& Roe, R.A. (2008). Beyond the three component model of organizational commitment. Journal of Applied Psychology, 93 (1), 70-83.

Somers, M.J. (1995). Organizational commitment, turnover and absenteeism: An examination of direct and interaction effects. Journal of Organizational Behavior, 16:49-58.

Steers, R.M. (1977). Antecedents and Outcomes of Organizational Commitment. Administrative Science Quarterly, 22, 46-56.

Su, S., Baird, K., \& Blair, B. (2012). Employee organizational commitment in the Australian public sector. International Journal of Human Resource Management, 24, 2, 243-264.

Tetrick E. , Shore L., \& McFarlane, L. (1991). A Construct Validity Study of the Survey of Perceived Organizational Support. Journal of Applied Psychology, 76(5), 637-643.

Tett, R.P., Meyer, J.P. (1993). Job satisfaction, organizational commitment, turnover intention, and turnover: path analysis based on meta-analytic findings. Personnel Psychology, 46 (2), 342-346.

The Egyptian Hotel Guide. (2016). 34 ${ }^{\text {th }}$ ed. Cairo, Egyptian Hotel Association. 
Tufail, M., \& Naveed, F. (2012). Component Wise Comparison of the Degree of Organizational Commitment. International Review of Management and Business Research. 1(1), 47-53.

UK Essays. (2015). Employee advocacy overview. Reviewed Feb. 13,2018, from http://www.ukessays.com/easys/management/hr-employee-advocates-main-tasksmanagement - essay-php.

Uludag, O., Khan, S., \& Güden, N. (2011). The Effects of Job Satisfaction, Organizational Commitment, Organizational Citizenship Behavior on Turnover Intentions. FIU Review, 29(2):1-21. Urban, G.L. (2004). The emerging era of customer advocacy. MIT Sloan Management Review, 45 (2), 77-82.

Wallace, E., de Chernatony, L., \& Buil, I. (2013). Building bank brands: how leadership behavior influences employee commitment. Journal of Business Review, $66(2), 165-171$.

Wayne, S. J., Shore, L. M., Bommer, W. H., \& Tetrick, L. E. (2002). The role of fair treatment and rewards in perceptions of organizational support and leader member exchange. Journal of Applied Psychology, 87, 590-598.

Wayne, S.J., Shore, L.M., \& Liden, R.C. (1997). Perceived organizational support and leader-member exchange: a social exchange perspective. Academy of Management Journal, 40, 82-111.

Weiner, Y. (1982). Commitment in Organization: A Normative View. Academy of Management Review, 7, 418-428.

Weng, Q. X., McElroy, J. C., Morrow, P. C., \& Liu, R. (2010). The relationship between career growth and organizational commitment. Journal of Vocational Behavior, 77(3), 391-400.

Yeh, Y.P. (2014). Exploring the 1mpacts of employee advocacy on job satisfaction and organizational commitment: Case of Taiwanese Airlines. Journal of Air Transport Management, 1 (36), 94-100. 